\title{
Waste Management and its Contestation in the Republic of Ireland*
}

\author{
G. Honor Fagan
}

\begin{abstract}
I'll tell you what I see here, Sims. The scenery of the future. Eventually the only scenery left. The more toxic the waste, the greater the effort and expense a tourist will be willing to tolerate in order to visit the site. Only I don't think you ought to be isolating these sites. Isolate the toxic sites, okay. This makes it grander, more ominous and magical. But basic household waste ought to be placed in the cities that produce it. Bring garbage out into the open. Let people see it and respect it. Don't hide your waste facilities. Make an architecture of waste. Design gorgeous buildings to recycle waste and invite people to collect their own garbage and bring it with them to the press rams and conveyors. Get to know your garbage. And the hot stuff, the chemical waste, the nuclear waste, this becomes a remote landscape of nostalgia. Bus tours and postcards, I guarantee it. ${ }^{1}$
\end{abstract}

\section{Introduction}

In 1979 Immanuel Wallerstein drew up a comprehensive list of countries deemed "semi-peripheral:" Portugal and Spain, Greece and Turkey, Brazil and Mexico, Canada and Australia, and "most of Eastern Europe" were all there but not Ireland. ${ }^{2}$ However, the Republic of Ireland seems to be a textbook case of semi-peripherality. The semi-periphery was first conceptualized as a residual category, part of the intermediate zone between the core and the periphery of the world system. It was seen as a transitional stage of development from which a country could progress "upwards" or "downwards" in the world-system hierarchy. Later, the semi-periphery was redefined as a permanent and stable part of the global economy, now seen as tri-modal and not as a simple core-periphery binary opposition. ${ }^{3}$ However, despite this clarification, "semi-periphery" has remained a contested concept for a number of reasons. ${ }^{4}$

\footnotetext{
${ }^{*}$ I would like to thank Andrew Biro for his comments on an earlier draft and the colleagues who worked on the research project with me: Denis O'Hearn, Michael Murray, Gerard Mc Cann and Ronaldo Munck. An earlier version of this paper appeared in Irish Journal of Sociology, 12, 1, 2003.

${ }^{1}$ Don DeLillo, Underworld (New York: Scribner, 2000), p. 286.

${ }^{2}$ Immanuel Wallerstein, The Capitalist World Economy (London: Cambridge University Press, 1979).

${ }^{3}$ See Giovanni Arrighi, ed., Semi-Peripheral Development (Beverly Hills: Sage, 1985).

${ }^{4}$ See in particular Peter Lange, "Semiperiphery and Core in the European Context," in ibid.; C. Terlouw, "The Elusive Semiperiphery: A Critical Examination of The Concept of Semiperiphery," International Journal of Comparative Sociology, 34, 1-2, 1993.
} 
The great diversity of states that at one time or another have been dubbed semiperipheral raises the issue of conceptual clarity and consistency. The conventional definition of semi-periphery used hitherto is based on the balance of economic activities between industrial goods and primary products, categorizations with less salience in the "information society." However, the concept could be updated in terms of the balance between "intellectual" and "execution" activities carried out by transnational corporations in different locations, for example in relation to the global telecommunications sector. Then we would also need to distinguish between "economic" and "political" semi-peripherality: Australia and Ireland may in economic terms enter this category but they are not in the same "political" category of semi-peripherality as, say, Pakistan or Indonesia. Then we would need to specify the political implications of the category. Christopher Chase-Dunn has focused on the semi-periphery as the "weak link" of the world system and the locus of transformative social movements. ${ }^{5}$ Wallerstein has, since his earlier writings on the topic, focused on the "concentration of state-oriented political activity" in the semi-peripheral nationstates. Taking up the more "relational" definition of semi-periphery as articulated in the introduction to the December 2003 issue of $C N S$, I propose to examine whether semi-peripherality has a specific effect on waste management in Ireland and the accompanying resistance to government plans and strategies to deal with it.

The economic development of Ireland has, on the whole, been studied from a modernization perspective. A few voices did introduce a broadly dependency theory influenced perspective, but the concept of semi-peripherality was more implicit than explicit in these accounts. ${ }^{7}$ However, Ireland clearly represents a case of semiperipherality broadly understood; it is not a core country, it still suffers from the legacies of colonialism, but it no longer stands as a classic case of dependency à la André Gunder Frank. ${ }^{8}$ Denis O' Hearn notes that while "Ireland's narrow dependence on American TNCs makes a return to the dark days of the 1980s a strong possibility," it was still the case that "[s]everal years of rapid economic growth have brought very real changes to the South of Ireland." That is to say, we need to understand the accelerated economic development of the 1990s and beyond in terms of Ireland's semi-peripherality, rather than its magical transformation into a core member of the new global economy. One would be tempted to say that Ireland is not a "globalizer" although it has clearly been "globalized." When Ireland joined the European Union in 1973 it began to grow away from the semi-colonial relationship it still maintained with Britain at the economic level, only to become an integral part of the expanding

\footnotetext{
${ }^{5}$ Christopher Chase-Dunn, "Resistance to Imperialism: Semi-Peripheral Actors," Review, 13, 1990.

${ }^{6}$ Immanuel Wallerstein, "The Relevance of the Concept of Semiperiphery to Southern Europe," in Arrighi, op. cit., p. 35.

${ }^{7}$ Denis O'Hearn, "The Irish Case of Dependency: An Exception to the Exceptions?" American Sociological Review, 54, 4, 1989; Ronnie Munck, The Irish Economy: Results and Prospects (London: Pluto, 1993); Peadar Kirby, The Celtic Tiger in Distress: Growth with Inequality in Ireland (Houndmills and New York: Palgrave, 2002).

${ }^{8}$ See, for example, André Gunder Frank, Capitalism and Underdevelopment in Latin America (New York: Monthly Review Press, 1969).

${ }^{9} \mathrm{O}$ 'Hearn, op. cit.
} 
US economy in Western Europe, as American corporations were keen to establish a foothold in semi-peripheral locations such as Ireland. By joining the Euro-zone the Irish economy is effectively tied in to the pattern of development set by the core European economies. On the other hand, economic dependence on the US has dramatically increased in recent years with the emergence of the "new economy" based on the pharmaceutical and computing industries. So much so that Damien Kiberd, economic editor of the establishment Sunday Times can now declare in an uncontroversial manner that: "[t]he Irish economy is now little more than a branch economy of the United States. It is hugely dependent on the trading climate in corporate America and the flow of foreign direct investment (FDI)., ${ }^{\prime 10}$ In this context the undoubted economic boom in Ireland over the last decade begins to look more fragile insofar as it is almost totally dependent on the evolution of the US economy. This does not recreate a classic situation of dependency, however, and we must recognize that Ireland's new found economic dynamism places it in the category of semi-periphery, betwixt and between the center and the periphery, both economically and politically.

While the concept of semi-peripherality thus serves to situate Ireland structurally in the global system, it has certain limitations. The concept in its classic manifestations is rather static and state-centric in its optic. Recently Ireland has been analyzed more in terms of the interactions between culture, society and the global economy ${ }^{11}$ with the concept of "hybridity" coming to the fore, even among analysts who had previously analyzed Ireland in terms of dependent development. ${ }^{12}$ This more "poststructuralist" and culturally aware perspective is a necessary supplement to more economistic renderings of semi-peripherality. The Republic is an integral part of the economic flows and instabilities created by the vastly accelerated process of economic internationalization over the last decade. While Ireland may well be a "branch economy" of the US, it is also a "place" with "local" issues and political struggles. These places are best conceived, I would argue, through a "glocal" lens that merges the local and the global in a new hybrid socio-economic formation. ${ }^{13}$ According to Arif Dirlik "'Glocal' expresses cogently what Bruno Latour has in mind by the hybridity of the global and the local. What it forces us to think about is a double process at work in shaping the world: the localization of the global, and the globalization of the local." 14

In methodological terms, the largely disembodied "global" studies and the detailed ethnographic "local" studies could thus be superseded by a new mode of "critical grounded" study of the glocal. The rather diffuse concept of the glocal does not, however, displace that of semi-periphery, but rather acts as a bridging

\footnotetext{
${ }^{10}$ Damien Kiberd, "Open Ireland Inc to Private Investment," Sunday Times, November 24th, 2002.

${ }^{11}$ Peadar Kirby, Luke Gibbons and Michael Cronin, eds., Reinventing Ireland: Culture, Society and the Global Economy (London: Pluto Press, 2002).

${ }^{12}$ Ronaldo Munck, "Globalisation, Development and Labour Struggles: Ireland in Context," Irish Journal of Sociology, 9, 1989.

${ }^{13}$ See Arturo Escobar, "Culture Sits in Places: Reflections on Globalism and Subaltern Strategies of Localization," Political Geography, 20, 2001.

${ }^{14}$ Arif Dirlik, "Place-Based Imagination: Globalism and the Politics of Place," Review xxii, 2, 1999, p. 158.
} 
concept that incorporates the global structural elements of semi-peripheral analysis, with local ethnographic place-based analysis. The growing waste management crisis in Ireland is a seemingly inevitable by-product of the recent economic boom. In this way Ireland is seen to be a typical semi-peripheral zone where economic dynamism is not matched by effective regulation, and where ecological degradation inevitably ensues. ${ }^{15}$ The pernicious ecological effects of the "Celtic Tiger's" neo-liberalism are most evident in its production and circulation of waste. A waste management crisis is one unintended (and fast spiraling out of control) outcome of its very recent economic success. Attempts to manage this waste management crisis have been center-stage in local politics throughout the Republic over the past two years and it is to this "crisis" that this article turns its attention.

In social theory waste can perhaps be seen as a "lost continent," a long way behind production and consumption in terms of analysis and understanding. It is only recently that we see the beginnings of a "sociology of waste"16 or a "political economy of waste." 17 I have recently collaborated on an all-Ireland empirical study of waste management ${ }^{18}$ and in this article I focus specifically on the geo-political situation of the regulation and management of waste in the Republic of Ireland. This article examines globalized networks of waste and globalized waste management networks as they impact this semi-periphery site. It looks at the competing actors that play a role in the governance of waste and analyzes the move towards a waste management strategy in terms of who is empowered or disempowered. It analyzes the competing discourses of neo-liberalism and Green politics as they play themselves out in the particularly intense "glocalized" contestation of waste management plans.

By focusing on waste and its governance in the Republic of Ireland we can shed light on a particularly intense arena of conflict and contestation where the global neo-liberal agenda has come into direct confrontation with the needs of ecology and democracy. From this space and place in the semi-periphery we can build insights into networks of wasting and the networked political processes of waste governance. How neo-liberalism has impacted waste governance, what other ideologies have impacted on it, who has promoted these ideologies, and how successful resistance to a neo-liberal agenda has been, are some of the questions I will address in this article. In order to answer these questions I will first examine the proposition that waste is a glocal fluid, that it is global and local at one and the same time. Secondly, I will examine the state's involvement in the development of a waste

\footnotetext{
${ }^{15}$ See Albert Bergesen and Tim Bartley, "World-system and Ecosytem," in T. Hall, ed., A World-System Reader: New Perspectives on Gender, Urbanism, Cultures, Indigenous Peoples, and Ecology (Boulder, CO: Rowan and Littlefield, 2000), p. 315; and David Smith, "Uneven Development and the Environment: Toward a World-system Perspective," Humboldt Journal of Social Relations, 20, 1, 1994.

${ }^{16}$ See Martin O'Brien, "Rubbish Values: Reflections on the Political Economy of Waste," Science as Culture, 8, 3, 1999.

${ }^{17}$ Robin Murray, Creating Wealth from Waste (London: Demos, 1999).

${ }^{18} \mathrm{G}$. Honor Fagan, Denis O'Hearn, Gerard McCann and Michael Murray, Waste Management Strategy:

A Cross Border Perspective (Maynooth: National Institute for Regional and Spatial Analysis, 2001).
} 
management strategy, the competing discourses informing its actions and its politics in terms of its adherence to notions of democracy. In particular I seek to assess whether Ireland's semi-peripheral condition leads to a particular lack of state control over environmental regulation. Finally, I will examine community action against incineration in terms of the nature of the resistance offered, how it is generated and its possible impact. This is related to the broader theoretical and political question of whether semi-peripherality creates the conditions for greater popular resistance in terms of both motive and opportunity. I also relate the waste management crisis in Ireland to the complex "politics of scale" that frame this issue in global, regional, national and local terms.

\section{Waste as Glocal Fluid}

Waste is part of global networks that are material, technical, social and discursive. Of particular interest is the fact that waste poses sharply the issue of regulation in a global economy where the dominant discourse is deregulatory and in favor of "free market" operations. A network can be defined as a set of inter-connected nodes, a dynamic and flexible open structure, and the global economy is connected by "global commodity chains." ${ }^{19}$ The environmental/waste issue, while it can be seen to be subject to commodity/care chains, is perhaps best conceptualized as a "global fluid." Those are, according to Urry, "flows or waves of people, information, objects, images, risk and networks across regions in heterogeneous, uneven, unpredictable and often unplanned shapes." ${ }^{20}$ Waste is a global fluid, but it is usually invisible, deemed unproductive and certainly not well researched.

Waste could be conceptualized as a globally circulating fluid, its production and management governed well beyond the nation state. A recent study on globalization and the environment sees environmental flows as particularly global: "[ $[$ ] his is particularly true for flows related to the environment: greenhouse gases, ozone threatening gases and toxic wastes move from more developed to less developed countries; raw materials and commodities, produced at huge environmental costs flow from less developed to more developed countries." ${ }^{21}$ In the 1970s and 1980s, the ecological debate shifted from the national to the global terrain. This debate focused on the "limits to growth," the need for production to be "sustainable" and for consumption to be cut back. The Chernobyl disaster of 1986 brought home in a dramatic way the transnational characteristics of ecology. The Rio "Earth Summit" of 1992 may have

\footnotetext{
${ }^{19}$ Garry Gereffi, "The Organization of Buyer-Driven Global Commodity Chains: How US Retailers Shape Overseas Production," in Garry Gereffi and Miguel Korzeniewicz, eds., Commodity Chains and Global Capitalism (Connecitut: Praeger, 1994).

${ }^{20}$ John Urry, "Time, Complexity and the Global," published by the Department of Sociology, Lancaster University at: http://www.comp.lancs.ac.uk/sociology/soc057ju.html 2000, p. 5.

${ }^{21}$ John Urry, "Global Citizenship and the Environment: An ESRC Funded Research Project," published by the Department of Sociology, Lancaster University at: <http://www.comp.lancs.ac.uk/sociology/ jures.html>, 1999.
} 
produced the international declaration, but it was Chernobyl (and Seveso) that produced a real social understanding of the biosphere as a single integrated whole. As Robin Murray puts it:

As environmental concerns came to the fore in the 1990 s, all roads led to waste. From centuries of obscurity the waste industry found itself at the hub of environmental argument. ${ }^{22}$

Ironically, as the wave of international neo-liberal economics was peaking, the government's response to the environmental threat, and waste in particular, was to increase and strengthen environmental and waste regulations. Waste emerged from obscurity to threaten the consistency and symmetry of the dominant neo-liberal discourse. The irony was that to make waste profitable, it needed to be regulated.

Waste has broken down the earth's natural limits, and its risk factors are multiplying. Wasting is likewise posing dramatic regulatory problems, and its flows are recognized as well out of control. In Europe the Environmental Agency presents the chaotic scenario:

The expected waste trends during the outlook period [up to 2005] suggest that existing policies, although providing some degree of success, will not be sufficient to stabilize waste arising, meet policy objectives, or progress towards sustainability. ${ }^{23}$

In the waste categories more familiar to the domestic consumer such as paper, cardboard, glass, and plastic, proposed recycling efforts offer only a partial solution. Many countries have adopted increased recycling, but according to the European Environmental Agency, the development "has been only a partial success, because the total amount of waste paper and waste glass (container glass) generation has also increased in the same period. ${ }^{24}$ The sheer material quantity of waste in circulation is extraordinary. The European Environmental Agency's statistics on the European Union for 1999 show two billion tonnes of waste being generated per year and that the amount has increased by ten percent each of the previous six years. It estimates that all waste streams will continue to increase steadily. ${ }^{25}$

Contemporary patterns of waste flows are historically unprecedented. Trade in toxic wastes occurs at the transnational level, with toxic wastes changing hands between the global North and the global South in profitable and usually environmentally hazardous ways. ${ }^{26}$ The emergence of any form of regulation is relatively new. Before the 1970s the free market criteria of "produce what you want so long as

\footnotetext{
${ }^{22}$ Murray, op. cit., p. 20.

${ }^{23}$ European Environment Agency, Environment in the European Union at the Turn of the Century (Luxemburg: EC Publications, 1999), p. 215

${ }^{24}$ Ibid., p. 203.

${ }^{25}$ Ibid.

${ }^{26}$ Greenpeace, The International Trade in Toxic Wastes: An International Inventory (Washington: Greenpeace International, 1993).
} 
you can make a profit," prevailed. Most Organization of Economic Cooperation and Development (OECD) countries did not even have an analytical or legal framework for distinguishing between different types of waste. In Foucaultian terms, without definition, without naming, without statistical information, the regulation of waste was simply impossible.

Waste scandals such as the Love Canal incident in the US and the BT Chemie scandals in Sweden brought about the definition of certain wastes as hazardous ${ }^{27}$ and created the possibilities for its regulation. Governance moves were made at the global level to create a common global list of agreed hazardous wastes, and ironically, this list has been a "driving force" establishing profitability of the international trade in hazardous waste. ${ }^{28}$ The regulation of waste is approached from many other spheres of governance. The global sphere deals particularly with hazardous and toxic wastes. At a European level, nation states are now required to manage waste under specific European guidelines, which must be adhered to under pain of severe financial penalties. It is this naming and differentiation between wastes, and the shift towards their regulation that has established a profitable market for waste.

The material quantity of the waste circulating in the Republic of Ireland is equally astonishing to those blinded to the social process of wasting. Like in all European Union countries, the quantity is increasing all the time. However, in the Republic of Ireland there is an above average growth rate in its production due to the economic boom of the "Celtic Tiger." Between 1995 and 1998, waste flows in Ireland increased by a phenomenal 89 percent. Most of this waste (currently 91 percent of municipal waste and 85 percent of industrial waste) is "disposed" of through landfill, which is clearly the most environmentally risky option. ${ }^{29}$ Being grounded, of course, does not block waste's continuous circulation as environmental scientists and community residents beside landfill sites testify. Hazardous wastes are also shipped out of the country to other European sites.

While we can see waste as a global fluid, with risk and profitability associated with its movement, so too can we conceptualize it as being locally networked at the most micro level. If we start at the local site of the individual and their waste bin, we can see that each person in the Republic of Ireland is "producing" practically double the European average of one kilogram of municipal waste per day. The Irish Environmental Protection Agency (EPA) ${ }^{30}$ estimates that every citizen of the Republic is producing an average of $600 \mathrm{~kg}$ of waste a year. In doing so they are actively engaged in relating to a social process and social relations of wasting through their pattern of consumption. Consumers purchase what has been produced in the format it is being produced in. Citizens have some choice in this area as some forms of

\footnotetext{
${ }^{27}$ David Held, Anthony McGrew, David Goldblatt and Jonathan Perraton, Global Transformations: Politics, Economics and Culture (Cambridge: Polity, 1999), p. 407.

${ }^{28} \mathrm{Ibid}$., p. 408.

${ }^{29}$ Environmental Protection Agency, Environment in Focus, 2002: Key Environmental Indicators for Ireland (Dublin: Environmental Protection Agency, 2002), p. 9.

${ }^{30}$ Ibid.
} 
consumption are more environmentally "friendly" than others, but, by and large consumerism is organized along lines more concerned with profitability than with a sustainable environment. Can the individual consumer be interpellated as an environmentally concerned consumer and can some or all markets respond to this trend? ${ }^{31}$ We are left with the fact that on average the contents of the waste bin are becoming greater, there are more of them, and there are things in them that are worse for the environment than ever before. While the individual may not be producing the hair spray canister, the plastic tractor or the twenty-one so-called "disposable" diapers (surely a misnomer for something that simply cannot be gotten rid of and takes longer to decompose than the old cloth diapers) they are playing a role in its wasting. In other words, the consumption pattern of the household results in the waste bin, acknowledging that this could be a very different waste bin if the forces of production were regulated into producing less wasteful and environmentally damaging commodities.

The organization of the waste bin once filled is that it is "put out" (colloquial term for placing bins outside the household for collection), to be dealt with at sub-state regional and national level, where its malign geographic footprint becomes more visible on the Irish environment. Its management at this point becomes part of a governance network: Who are the actors, the key players and what are the key "drivers" embedded in these governing networks? In taking a "grounded and processual" approach $^{32}$ to the development of Irish waste management strategy as a social effect we have begun to answer these questions. ${ }^{33}$ Given that waste is a material outcome of globalized consumerism and "development," who are the key players in its management? Who governs, regulates and strategizes waste flows in the semi-peripheral site of Ireland?

\section{Regimes of Governance: EU and the Nation-state}

In the study we carried out ${ }^{34}$ there was very little doubt as to who were the key actors when respondents were presented with a range of possible "players." EU governance was considered to be the key driver, and there the evidence suggests that this is indeed the case. In this sense Ireland's semi-peripherality is clear, insofar as key decisions are made by the European Union, itself dominated by the larger core capitalist states such as Britain, Germany and France. The European Economic Community (EC) Act of 1972 gave "direct effect" to European acts over domestic laws and constitutional provisions in the Republic and in Northern Ireland. The ratification of the Single European Act (1986), the Treaty of Maastricht (1992), and the Treaty of Amsterdam (1997) further ensured the supremacy of EU law over domestic law.

${ }^{31}$ See the debates in Timothy Luke, "Green Consumerism: Ecology and the Use of Recycling," in Ecocritique (Minneapolis: University of Minnesotta Press, 1977).

${ }^{32}$ Sarah Radcliffe, "Development, the State and Transnational Connections: State and Subject Formations in Latin America," Global Networks, 1, 1, 2001.

${ }^{33}$ Fagan, et al, op. cit.

${ }^{34}$ Ibid. 
EU legislation includes Directives on dangerous substances, waste oils, groundwater, urban waste water, licensing regulations, the disposal of PCB/PCT, toxic waste, sewage sludge in agriculture, emissions from waste incineration plants, the disposal of animal waste, and batteries containing dangerous fluids. The extent of the national Irish input is that at the European level includes some participation in the discussion and decision-making given that the EU is a network made up of nation states. When the Directives are in place, the nation state, has some leeway with the "how and when" of implementation in their own jurisdiction.

While EU Directives do set out a stated time period for implementation, it is up to individual member states to decide how the individual Directive is to be given effect. Directives, therefore, are not directly or immediately applicable to domestic law. However, failure to implement a Directive within the given period of time can result in a member state being penalized by the European Court of Justice. Early EU Directives were of particular relevance to the formation of Irish and UK government policies on waste management including Council Directive 75/442/EEC - July 1975, which states that member states must encourage steps that prevent and minimize waste flows. These include recycling and the extraction of raw materials and energy for re-use of waste (Article 3). It also notes that Member States must ensure that waste is disposed of "without endangering human health and without harming the environment, and in particular: without risk to water, soil, and plants and animals, without causing a nuisance through noise or odours, without adversely affecting the countryside or places of special interest" (Article 4). Thus the "green" quality of the regulations is firmly in place.

This Directive was later reinforced to ensure that the EU as a whole, and member states individually, aim towards self-sufficiency in waste disposal (Article 5, Council Directive 91/156/EEC [March 1991] amendment to Directive 75/442/ EEC). Furthermore, the EU wanted the establishment of "a competent authority" in order to plan, authorize and supervise waste disposal operations (Article 5). This plan was to include the type and quantity of waste, suitable disposal sites, costs, and "appropriate measures to encourage rationalization, of the collection, sorting and treatment of waste" (Article 6). The authority was also charged with issuing permits to those who store or tip waste on behalf of a third party (Article 8), and was to ensure that the conditions of the permit are fulfilled thereafter. As a sanction against default, waste costs would be in accordance with the "polluter pays" principle (Article 11).

In sum, the EU is a key player determining the regulation of waste, and the EU legislation impacts the development of strategy at the national level in a dramatic demonstration of the "politics of scale" (see below). ${ }^{35}$ EU policy emerges from a network of actors and competing agendas and in the regulation of waste we can clearly see the agenda informed by sustainable environment concerns. This legislation clearly

\footnotetext{
${ }^{35}$ On the local implementation "deficit" in Ireland see Anthony Quinlivan, "European Standards and Waste Management in Ireland: Examining the Local Implementation Deficit," Administration, 50, 2, 2002.
} 
reflects networked green politics, but at the European level the contradiction between the concepts of development (market-driven in its capitalist form) and sustainability (the earth as limited resource) are also played out.

Moving from European level to the nation state "level" it is necessary to examine the current debate on the nature of the contemporary state, which is directly relevant to the analysis of the state's role in waste management strategy. Philip Cerny argues that there is a "competition state" driving globalization on, and eroding the "insideoutside" nation-state distinction. ${ }^{36}$ The state is transformed, but its much-vaunted death proclaimed in early globalization studies has not occurred. Martin Carnoy and Manuel Castells ${ }^{37}$ also show how far we have come from the classic 1970 s statement of Marxist state theory by Nicos Poulantzas. They argue that the state can now best be described as a "network state," just one player among others when it comes to control of knowledge and information. Globalization, time space-compression and the information society have created a new network state that is "made of shared institutions, and enacted by bargaining and interactive iteration all along the chain of decision making" 38 from the supranational to local government and NGO's. Decision-making and representation take place all along the chain, and not necessarily in a hierarchical pre-scripted order. The new state "functions as a network in which all nodes interact, and are equally necessary for the performance of the state's functions." 39

While Carnoy and Castells assert that all nodes are equally necessary, the development of waste management strategy suggests that some nodes are distinctly "more equal than others." With the EU able to enforce sanctions on the nation state and the national governments needing to radically change the waste flows, drawing up and implementing of strategy quickly becomes an issue of governance in the networked society. As Gerry Stoker puts it, "governance recognizes the blurring of boundaries and responsibilities for tackling social and economic issues." ${ }^{, 0}$ Both in terms of strategic decision-making and of service delivery there is a widespread turn away from the hierarchical Westminster model of decision-making and government to a more networked model of governance more in-line with the complex networked societies we live in. In terms of waste management strategy, government by central decree would be an impossibility. Governments thus attempt to move to a strategy based on a more consensual model based on multi-agency partnerships. Self-governing networks in relation to waste management would, from this perspective, be much favored. The "capacity to get things done" does not simply rest on the power of

\footnotetext{
${ }^{36}$ Phil Cerny, "Structuring the Political Arena: Public Goods, States and Governance in a Globalizing World," in Ronen Palan, ed., Global Political Economy: Contemporary Themes (London: Routledge, 2000).

${ }^{37}$ Martin Carnoy and Manuel Castells, "Globalization, the Knowledge Society and the Network State," Global Networks, 1, 1, 2001.

${ }^{38}$ Ibid., p. 14.

${ }^{39}$ Ibid.

${ }^{40}$ Gerry Stoker, "Governance as Theory: Five Propositions," Journal of International Social Science, 155, 1998 , p. 21.
} 
government to command, but on developing new mechanisms to steer and guide. Waste governance, from this perspective, will not be resolved at its most radical level of sustainability ${ }^{41}$ without widespread social and political consensus. For most governments to reach the targets it is necessary to bring key players such as "private enterprise" into some form of partnership. They can achieve this with a "stick" if necessary, as they are the body responsible for regulating waste production, but in line with the governance strategy the preferred option would be to achieve this with a "carrot" approach. Current Minister for the Environment, Martin Cullen, is seeking initiatives from the private sector to reduce waste going to landfill but declares, "[w]here initiatives are not forthcoming, I will not hesitate to regulate." ${ }^{42}$

The development of waste management strategy at the national level does point to the state as networked. It is in fact the transnational politics of EU policy that has forced the nation state to carry out policies in this case. There was widespread consensus across the spectrum of waste management "actors" that "[w]aste management began to be driven more and more by the EU. The EU demanded that we manage our landfills better, they demanded an end to pollution." ${ }^{, 43}$ It is also evident that the policy built at the European level was fed into by the nation state, but also influenced by a transnational environmentalist movement. In our study the environmentalists, the environmental scientists, and the environmentally minded politicians were extremely happy with the EU Directives. They were considered to contain an "alternative world view" on "sustainable development" which had, at least in part, come from the "drive of civil society and NGO's" concerned with environmental issues. ${ }^{44}$ So there is no doubt that the state functions more like a node in a network, charged with implementing EU Directives at national and local level, rather than as a centralized headquarters.

EU policy on waste is, indeed, partially driven by civil society in the form of the environmental movement, but that policy implementation is opposed at the local level by the same elements of civil society with many of the same environmental concerns that drove policy in the first place. Our all-Ireland waste study points to the state acting to "filter out" those elements of the EU policy that are seen as more threatening to powerful interest groups. State strategies such as "individualization" (where domestic householder's waste was emphasized over and above agricultural and industrial waste), and marketization (where they try to make the final waste product "profitable") were seen to have been employed. They were present in the discourse of all of the players in the waste management strategy, even in that of those most radical environmentalists who would wish to emphasize sustainability over profitability. ${ }^{45}$

\footnotetext{
${ }^{41}$ Of course sustainability can be interpreted in a number of ways, from token or minimalist definitions through to a radical "zero waste" definition taken by authors such as Robin Murray, Zero Waste (Greenpeace Environmental Trust, 2002) or the "aesthetic of sustainability" as advocated by Kate Soper, "Nature Prospect," CNS, 14, 2, 2003.

${ }^{42}$ Quoted in Frank Mc Donald, "Minister Wants to Fast-Track Planning on Waste," Irish Times, August 12, 2002 , p. 2.

${ }^{43}$ Fagan, et al, op. cit., p. 42.

${ }^{44}$ Ibid., p. 10

${ }^{45}$ Ibid., pp. $41-42$.
} 
When it comes to the implementation of these Directives at national level, the tension played out is most certainly between questions of sustainability (which regions and localities seem to be pushing more than the state) and questions of profitability (spoken for by industry and increasingly spoken for by the state). The question of financing the infrastructure for dealing with waste appears to be the most urgent side of the equation at the national level in order to meet $\mathrm{EU}$ waste targets.

\section{Democratic Discourses and "Glocal" Struggles}

Waste is a global fluid and therefore a global issue, but it is also clearly a local issue. So, as already mentioned, I shall deploy the concept of the "glocal." That is to say that waste is at one and the same time global and local, thus glocal. It is created in someone's locality and dumped or burned in a locality, yet it also flows around globally. The political economy of waste can thus be seen as embedded in multiple and inter-locking locales.

The relation between the global and the local is never a straightforward one. When it comes to analyzing political action around waste management strategy from the point of view of networked political action, we can see a complex dynamic in play. For some progressive (and not so progressive!) social or political movements, the global represents an unquestionable "bad," compared to the uncomplicatedly "good" local level. The global is seen as the terrain of capital while the local is the terrain of the people. Yet, as Doreen Massey explains "setting up the question as local versus global is to accede to spatial fetishism...Imagining that space has a political meaning...to assume that the local is always better. . This is to side step the real problem. ${ }^{, 46} \mathrm{I}$ argue that local action is in fact glocal action precisely where it is networked political action. Political networks resemble the Gramscian concept of civil society in that they both enable and disable citizen participation and power. Castells makes a similar point when he argues that

dominant activities in our societies are made of networks: Global financial markets. . science and technology... the Internet as a universal, interactive communication network...[But] I would also add that increasingly, counter domination operates through networks as well. ${ }^{47}$

For Gramsci civil society was the realm in which the social order was grounded ("state = political society + civil society") but also where a new order could be founded through a process of social transformation. In terms of waste, the waste industry is clearly a global corporate network of considerable power and dynamism. The state is part of a network through the European Union. Political parties and campaigners active in the waste and environmental issues are also part of networks. But the question remains as to whether they all have equal capacities to be agents of social change.

\footnotetext{
${ }^{46}$ Doreen Massey, "The Geography of Power," Red Pepper, July, 2000, p. 8.

${ }^{47}$ Manuel Castells, "Globalization and Identity in the Network Society," Prometheus, 4, 2000, p. 110.
} 
One way of exploring these issues is through a consideration of how communities and activists contested the Irish government's preferred waste management strategy of building incinerators. In terms of participatory democracy the environmentalists and local communities threatened by incineration plans in Ireland were deeply critical of the "façade" of consultation that had occurred. They argued that the plan based on sub-regional incinerators developed by a company of engineers for the government:

goes out to the public for their "consultation," back come all these comments The engineering firm who have produced 90 percent of the plans, defends the plan against comments, and we get nowhere. ${ }^{48}$

Our study found a widespread perception that the government "consultations" (often dictated by EU regulations) on the development of incinerators were simply empty rhetorical exercises for communities to "let off steam" but not to change decisions already taken on "technical" grounds.

In Ireland the waste management strategy was thrown into political crisis throughout 2000-2001. Local communities successfully blocked the sub-regional plans. This marked a high point in the power of locals embedded in a geographical community, and a low point for the nation state. The state, however, reacted. The Minister at the time, Noel Dempsey, removed the local councillor from the decision making process (who had been subject to public will), and replaced her/him with the county manager, a government employee. In response to a challenge from "below," a central decree was used to achieve the localizing or embedding of waste management. This is not to say that the state moved entirely back to traditional government, rejected consensus politics and failed to involve itself in multi-agency partnership, but, rather, that they removed the locality from involvement in the decision-making process. The Environment Minister, Cullen, stated quite openly that the planning process on waste management was "over-democratized" ${ }^{49}$ and that he did not believe it was "adding anything to it by having so many layers involved." ${ }^{50}$ So "fast-tracking" of waste management plans had to be implemented, where An Board Pleánala (The Planning Board) became a "one-stop shop" for assessing all plans for new waste management facilities. Objectors must now raise their objections at An Board Pleànala hearings rather than at the local authority level. The Minister, in true Orwellian fashion, insists that he is not removing any groups' or individuals' rights to express their views, insisting that these rights are "sacrosanct, but I don't see a need for these views to be expressed at so many different levels."

There is currently a need for an estimated investment of one billion euros over a $3-5$ year period to implement the waste development plan, ${ }^{52}$ and the National

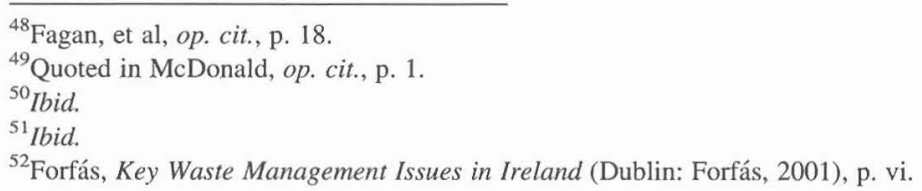


Development Plan envisages this coming from the private sector. Clearly, Ireland faces a grueling task to organize for targets set at a five-fold increase in recycling and to find the finance for the infrastructure, especially if the plan is for the private sector to answer the call. Private capital is thus seen as a necessary "node" in the governance of waste management and of major significance to its outcome, not a dispensable partner like the local community.

Waste is thus governed by a particular multi-faceted and shifting dynamic of actors with some gaining more power and others losing it in a complex political process. That local communities were important players in the dynamic is without question, but there were ebbs and flows in their political power. When waste hit the Irish scene as an issue it was on the basis of local concerns around landfills in the early eighties. This was an uphill struggle and local concerns received very limited acknowledgment from the state. It was EU Directives that resolved the conflict between communities and local government authorities on "waste disposal," not the national government. The Waste Management Act (1996) aimed to create more effective and defined roles for the Minister, the Environmental Protection Agency (EPA) and local authorities in relation to waste management, and was passed in direct response to European Directives. ${ }^{53}$ So local community opposition to landfill was strengthened by EU legislation and the Green argument was also strengthened and built on at the local community level. However, in regards to waste management strategy, environmental activists felt that the government "turned to incineration on the advice of one single engineering company" and "incineration was put into all the sub-regional plans" but not "up front." ${ }^{54}$ Incineration is a contested terrain, particularly since not one government policy or sub-regional plan mentions the word "incineration." The term that is used repeatedly, and pointedly, in a not so subtle discursive maneuver, is "thermal treatment plant." As in all conflicts the discourse itself marks the terrain and the use of word "incineration" as opposed to "thermal treatment plant" masks a political divide between those in favor of incineration and those against it.

In the case of waste, democracy has become troublesome for the Irish state. Communities are able to stretch their muscles and contest globalized networks in regards to locating incineration or "thermal treatment" plants in specific areas, but we also see how the state responds by simply enforcing decisions taken in the interests of capital in general and the waste management companies in particular. Resistance and community action play a key role in developing waste management strategy, but even more interesting from the point of view of resistance studies is that we see clearly how this action is glocal in the way it is networked to global community action. In one anti-incineration campaign we observed, the Internet being used from the very start to gain access to technical information and to build support from other similar groups. From as far away as Australia and from as close as Northern Ireland, technical

${ }^{53}$ Council Directive 75/442/EEC, July 1975 (Article 3) and the later amendment to this, Council Directive 91/156/EEC, March 1991 (Article 5).

${ }^{54}$ Fagan, et al, op. cit., p. 12. 
and organizing expertise flowed in. There seemed little doubt that the participants' view of the world was transformed by this experience, and while the campaign was embedded in a locale, it was clearly networked to the global environmental condition. Networking on environmental issues has become faster and more immediate due to the "network society." Environmentalism, in the era of globalization, supports and stimulates direct horizontal contacts between campaigners through the use of cyberpolitics and cybermedia. Evidence on the ground testified to Carnoy and Castells' argument that:

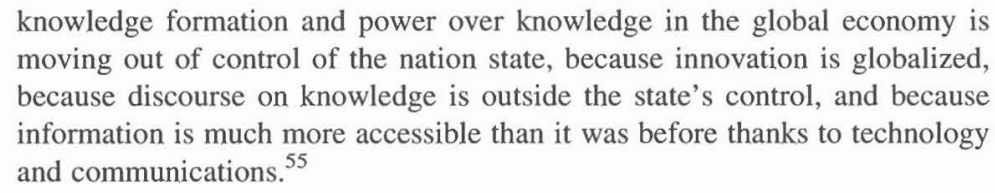

The first one community ${ }^{56}$ knew about an incineration plant being planned for their village was a sign in a field declaring that a planning application had been lodged. A quick search on the Internet by a local teacher revealed that the company making the application was a large waste treatment transnational. Soon concerned residents came together and the local parish priest joined the campaign to stop the incinerator being built in their small rural community. The government sought to portray this opposition as NIMBYism (Not In My Back Yard) based on concerns over the value of property rather than the health of the children. Undeterred, the campaign built up momentum and support was gathered internationally through the means of the Internet. Yet this was a very "local" campaign, based on the "social capital" resources of a tight-knit community.

As one of the residents we interviewed told us:

\begin{abstract}
And I'll tell you something else that we did as part of our campaign...we trawled the Internet ourselves for alternative technologies to incineration and we came up with several, one of which as a company called__ [company name]. We got them to come over to Ireland and we personally drove them down to the EPA with a view to letting them know that there were alternatives to incineration to solve the waste...
\end{abstract}

We believe in creating positive responses to waste management. ${ }^{57}$ The interviewee went on to say:

We're not proposing this as an alternative to incineration at all, there is no "magic machine" or anything, but it is an alternative and incineration is not the only answer because__ [company name] have alternatives that should be looked at, should be examined. We did that type of thing. We didn't say

\footnotetext{
${ }^{55}$ Carnoy and Castells, op. cit., p. 11.

${ }^{56}$ Fagan, et al, op. cit.

${ }^{57} \mathrm{Ibid}$.
} 
“we don't want an incinerator in our backyard." We said "look here's what you can do instead." We are very proactive and that is part of what we did. I mean. ... I took a day off work to bring these two visitors down to the EPA. So they certainly can't accuse us of NIMBYism. ${ }^{58}$

What was most noticeable was that this campaign - once successful in its main objective of stopping the incinerator - moved on to develop an integrated waste management scheme for the area based squarely on recycling. So what began as a particularistic "local" campaign became a general, more proactive long-term movement to create a sustainable environment. Not surprisingly, local residents felt that " $[\mathrm{t}] \mathrm{here}$ is no lead from the politicians. . the will just isn't there..."

Indeed, as one resident told us:

The whole single-minded focus of this government seems to be to get incineration going quickly. And if the county councils won't push it through, then the central government will intervene and create a greater authority, whether it's a greater Dublin authority or a north-eastern authority, and get it in there. Because they see it perhaps as a cheaper alternative to landfills.... I don't really know what their justification is but it's a blind propaganda campaign from all angles. ${ }^{60}$

What is most remarkable is the extent to which the supposedly independent EPA in Ireland has also failed to lead on this matter. In 2002 the new Director General of the EPA declared that one of the EPA's difficulties in entering the public debate on waste disposal is that the Agency must adjudicate on licenses for incinerators so "taking a stand may compromise our ability to say yes or no." ${ }^{, 61}$ But the Director General of the state body charged with protecting the environment does, indeed, take a stand: "[p]ersonally, I would prefer to live beside an incinerator than a landfill site." ${ }^{\prime 2}$ Yet as our case study showed most people when faced with the prospect prefer to say "No to both the landfill and the incinerator."

In speaking to other actors contesting waste management plans outside the case study area there was considerable worry about the influence of commercial interests, specifically waste companies coming into the globalized waste market. The key worry from the environmentalists and local community activists was the role of "big business" (i.e. incineration companies) in the implementation of the plan. They argued that there had been aggressive attempts by incinerator companies to lobby the government ${ }^{63}$ and to lead strategy. As one put it "the incineration industry is a bit of a dying industry and so they are looking for new avenues, they are looking for new places to go

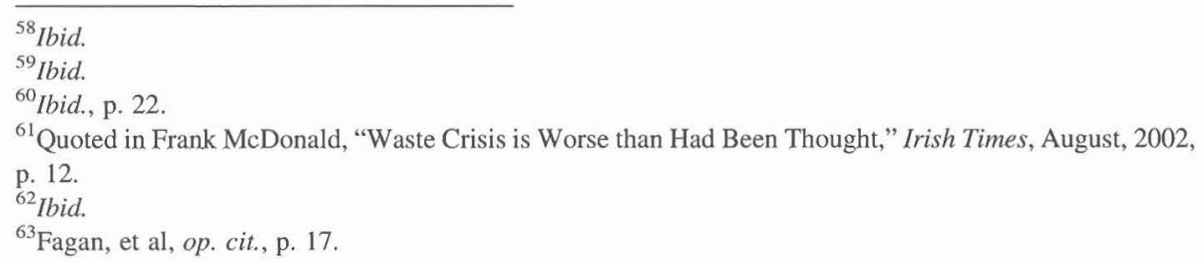


to build them, so they're looking to Eastern Europe and Ireland." ${ }^{64}$ This concurs with Martin O'Brien's interpretation of the waste industry where he argues:

This is a market whose rational economic actors are begging, cajoling, threatening and coercing the states of Europe to intervene politically into the circulation of wastes precisely because the "spontaneous" emergence of markets does not generate the values they want out of the rubbish heap. ${ }^{65}$

Many of our respondents felt that while the US and Japan were trying to get away from incineration, Europe was lagging behind because there were "vested interests" to be protected. The incineration companies were "well known" as multinationals, but they could "set up subsidiary companies" in Ireland. The environmentalists were paralleling the previous problem in the nation-states of local authorities acquiring and mismanaging landfill sites (i.e. the so-called "planning" of "dumping"), and the newer response of building incinerators. "Okay so we can't dump everything anymore, so let's just burn it," was the analysis. They believed that in both cases the government was "being wooed by or was wooing" large international companies and taking little responsibility for negative impacts on localized communities. ${ }^{66}$

The transnational linkages that inform national social movements and state-based issue actors demonstrate that subjects and spaces are formed in the interstices of complex political spaces that transcend national boundaries and state institutions. ${ }^{67}$ The negative view of incineration held by local communities, environmental campaigners and the environmental scientists was one informed by global flows of knowledge, political and technological, through mobile campaigners and cyberpolitics. The Irish government had turned to the "experts," the engineers, for a technical fix to the waste issue. An assumption was that they were the technocrats who held the key to the embedded knowledge and information of waste management. The surprising nature of the local action response was that it managed to link up, with a push of a button on the keyboard, to the cyberpolitics of international protest against waste. There was in practice a time-space intensification that aided the "local" response to a threat to the environment. The local action response was networked to a virtual community that could serve to disembed technical waste information and democratize it, taking it beyond "professional" discourses.

Most interesting then, above the fact that the new electronic media made possible a new kind of environmentalist - networked, flexible, media action oriented - is the interplay in the Irish situation between the politics of cyberspace and the politics of place. It is the dynamic interplay of these politics that makes them potentially most effective. As Arturo Escobar describes it, cyberpolitics can be effective if it fulfils two conditions: awareness of the dominant worlds (in this case the world of consumerism) and an ongoing tacking back and forth between cyberpolitics and political

\footnotetext{
${ }^{64}$ Ibid., p. 16.

${ }^{65}$ O'Brien, op. cit., p. 292.

${ }^{66}$ Fagan, et al, op. cit., pp. 16-17.

${ }^{67}$ Robin Cohen and Shirin Rai, eds., Global Social Movements (London: Athlone Press, 2000).
} 
activism in the place where the activist resides. ${ }^{68}$ The concept, or context, of semiperiphery allows us to situate the politics of resistance to current waste management practices. Incipient cyberpolitics and ongoing collective action against incinerators are part of a general global trend, but might also be seen as characteristic of the semi-periphery where issues are at their sharpest, and where resources and therefore contestation are present. That is to say, there is not only an awareness of what is wrong with the system but, also, there is a social, political and organizational capacity to resist. The "politics of scale" in Ireland can thus be conceived of in terms of Ireland's structural semi-peripheral condition.

There is now a growing body of evidence that electronic networks can be used to foster collective action. I am not referring here to electronic communication within an already existing transnational network of women, workers or environmentalists. Rather, I refer to these place-bound communities that Castells and others see as somehow static and lost in the whirlwind of globalization. Christopher Mele ${ }^{69}$ reports on the use of the Internet to build effective collective action in a low-income public housing development in North Carolina, and refers to how " $\mathrm{t}]$ he flexibility of the Internet proved useful in developing a surrogate electronic community and network and breaking down the isolation of Jervay and its residents." ${ }^{70}$ Something similar can be seen in the Irish anti-incineration campaigns. There is evidence that global forces and global connections, in this case may have inspired "social movements to seize control over their immediate but also their more distant worlds, challenging the mythology of an inexorable, runaway world."71

However, we need to bear in mind the enduring power of more traditional mediums such as newspapers and especially television, where the general population was effectively being convinced that indeed, there is no alternative to incineration. The neo-liberal discourse in relation to waste is no doubt a dominant one. Forfás, the National Policy and Advisory Board for Enterprise, Trade, Science, Technology and Innovation set up to advise the Minister for Enterprise, Trade and Employment on matters relating to the development of industry in the state, entered the fracas of waste governance in 2001 issuing a report titled Key Waste Management Issues in Ireland. This report sets waste management clearly in the context of industrial development where waste facilities are seen as "a factor towards the end" of maintaining competitiveness in the State's industrial policy. ${ }^{72}$ The report, according to the Tanaiste (Deputy Prime Minister) Mary Harney, is "timely and welcome as a

\footnotetext{
${ }^{68}$ Arturo Escobar, "Gender, Place and Networks: A Political Ecology of Cyberculture" in Wendy Harcourt ed., Women@Internet: Creating New Cultures in Cyberspace (London: Zed Books, 1999), p. 32.

${ }^{69}$ Christopher Mele, "Cyberspace and Disadvantaged Communities: The Internet as a Tool for Collective Action," in Marc Smith and Peter Kollock, eds., Communities in Cyberspace (London: Routledge, 1999). ${ }^{70}$ Ibid., p. 305.

${ }^{71}$ Michael Burawoy, "Introduction: Reaching for the Global," in Michael Burawoy, Joseph Blum, Sheba George, Zsuzsa Gille, Teresa Gowan, Lyn Haney. Maren Klawiter, Steven Lopez, Sean ÓRiain and Millie Thayer, Global Ethnography: Forces, Connections, and Imaginations in A Postmodern World (Berkeley: University of California Press, 2000), p. 29.

${ }^{72}$ Mary Harney in Forfás, op. cit., p. i.
} 
reasoned contribution to the current debate." 73 It does not take a social scientist to point out that waste management is a contested terrain in Ireland today - it is quite unavoidable if you read the paper or listen to the news - but a sociological perspective can usefully contextualize waste outside of the standard framework of industrial "competitiveness" and profitability.

\section{Conclusion}

Radical analysis in the era of globalization might be best served by producing "critical grounded" studies which may help link up different "places" in global political economy. Past models have included the radical "legislator" who uncovers the "laws" of capitalist development, and the Gramscian "organic intellectual" tied umbilically to a social movement. Today requires a more mobile, traveling, or interpretative role to be effective. Michael Burawoy refers to "the ethnographic archaeologist who seeks out local experiments, new institutional forms, real utopias if you wish, who places them in context, translates them into a common language and links them one to another across the globe." ${ }^{74}$ This traveling ethnographer would be "grounded" and she would, hopefully, be imbued with the spirit of social transformation.

Apart from the specific issue of waste management, a major theme flowing from the above study is the issue of multi-scalar governance. The recent debates on the "politics of scale"75 provide a powerful analytical tool to analyze the issues of globalization, semi-peripherality and the environment. These debates see social interactions as having a spatial or geographical structure. The households in the small rural community used in this study as a case study for an anti-incinerator campaign relate to national political structures, macro-regional European dimensions and to the global environmental movement. The campaign against the proposed incinerator was successful in "jumping scales" and making global alliances for a "local" campaign. Yet the politics of scale is more than a "level" of analysis and needs to be seen "as a relational element in a complex mix that also includes space, place and environment. .. which interactively make the geographies we live in."76 This is a problematic which could usefully illuminate the waste management processes discussed above.

The politics of scale may provide us with a more nuanced way of understanding local politics but also of how governance is today, inevitably, a "multi-scalar"

\footnotetext{
${ }^{73}$ Ibid., my italics.

${ }^{74}$ Michael Burawoy, Foundations of a Sociological Marxism: The Complementary Convergence of Antonio Gramsci and Karl Polanyi (Berkeley: University of California, 2002), p. 65.

${ }^{75}$ See Sallie Marston, "The Social Construction of Scale," Progress in Human Geography, 24, 2000; Sallie Marston and Neil Smith, "States, Scales and Households: Limits to Scale Thinking?" Progress in Human Geography, 25, 2001; and Neil Brenner, "The Limits To Scale? Methodological Reflections on Scalar Structuration," Progress in Human Geography, 25, 2001.

${ }^{76}$ Marston, op. cit., p. 221.
} 
process. Waste management in this study was demonstrated to be both local and global, while a main "driver" at policy level was the macro-regional European level. The campaigns against the Irish government's incinerator-based waste management strategy were inevitably place-specific. This approach focused on the uneven development of scale and its social dimensions; this certainly takes us beyond static categories of core, periphery and semi-periphery, which once prevailed, but is compatible with the more nuanced approach taken in this issue of CNS. The complexity of social life under late capitalism cannot be pigeonholed too neatly. As Neil Brenner puts it, debates on the politics of scale provide "an important theoretical lens through which to begin to decipher the dramatic and highly unsettling processes of rescaling of capital, of the territorial state and of social power relations more generally - that are occurring throughout the world system in the current era of "glocalization."77

Does Ireland's semi-peripherality create a specific dynamic for waste management politics? While an economic boom has undoubtedly eased core-periphery tensions within the EU it has also heightened some contradictions. As we saw above, Ireland's semi-peripheral status provided the impetus for a dependent but real level of development since the 1990s. However, the ecological consequences of this were not faced by a semi-peripheral state that responded passively to EU Directives on the matter. Ireland's continued dependence on the structures of "Empire" has created a dependent political structure and outlook. Characteristic of this, as we saw above, is a total failure to engage with strategic long-term thinking on the vital ecological issue of waste management. As found in our interviews within the Irish state, there was a simple forlorn hope that Ireland could once again obtain "derogation" (be excused) from the various pressing European Directives on waste management in a typical semi-peripheral dependent manner.

If Ireland is a "branch economy" of the US then its political managers will inevitably tend to run the country like a corporation. Issues of legitimacy and democracy are translated into the language of cost-benefit analysis. Waste is an issue to be tackled as expeditiously as possible: if we can no longer bury it in the ground then we should burn it; if the electorate do not like this then we should "educate" them better. While the managers of the state can keep the economy booming and "dividends" are paid out regularly to the "share-holders" in the national economy, this system is only stable in the short-term. It is now clear that the economic boom is fragile (because it is dependent on US economy swings), and time-limited (already it is faltering). In the next three to four years Ireland is due to become a net contributor to the EU, losing the special privileges it has enjoyed hitherto - yet another contradiction of the economic boom that has not been faced. Semi-peripheral "success" as in Ireland not only brings disastrous eco-social consequences, but it is also notoriously unsustainable even within its own narrow logic.

\footnotetext{
${ }^{77}$ Brenner, op. cit., p. 603.
} 